\title{
Listening Text Type as a Variable Affecting Listening Comprehension Anxiety
}

\author{
Mehmet K1lıç \& Berrin Uçkun ${ }^{2}$ \\ ${ }^{1}$ School of Foreign Languages, University of Gaziantep, Gaziantep, Turkey \\ ${ }^{2}$ Retired scholar \\ Correspondence: Mehmet Kiliç, School of Foreign Languages, University of Gaziantep, Universite Bulvari, \\ 27310, Gaziantep, Turkey. Tel: 90-342-317-1671. E-mail: mekilic@gantep.edu.tr
}

\author{
Received: October 19, 2012 Accepted: November 27, 2012 Online Published: December 26, 2012 \\ doi:10.5539/elt.v6n2p55 URL: http://dx.doi.org/10.5539/elt.v6n2p55
}

\begin{abstract}
Every foreign language learner feels inadequate, ineffective or helpless at a certain period in the language learning process. Of the main reasons of these feelings, anxiety has been pronounced more frequently than the other affective variables in the literature. The primary concern of this research was to investigate the influence of listening text type on Foreign Language Listening Anxiety (FLLA), which is a skill-specific type of general language learning anxiety. The sample consisted of 130 students in the preparatory English classes of Gaziantep University. As a result of a series of one-way ANOVAs conducted on the data obtained from the FLLA scale and an anxometer (MacIntyre and Gardner, 1991), the current study demonstrated that listening text type is a distinctive factor for Foreign Language Listening Anxiety. Based on a comparison of text types in terms of their effects on listening anxiety, it was concluded that the authenticity of the listening text leads to more listening anxiety.
\end{abstract}

Keywords: foreign language listening anxiety, listening text type, affective variables

\section{Introduction}

\subsection{Introduction to the Problem}

Foreign language (FL) learners tend to feel inadequate, ineffective or helpless at a certain period during the language learning process. Usually, these feelings add up to create what is known as "anxiety". Anxiety literature suggests some possible arguments explaining why language learners become anxious. For instance, Horwitz, Horwitz and Cope (1986: 127) claim that foreign language anxiety is a specific type of anxiety related to foreign language learning, and their idea was supported by MacIntyre and Gardner $(1989,1991)$ and other theorists. They claim that language anxiety is a situation-specific type of general anxiety (trait anxiety).

Besides this general foreign language anxiety, it is generally accepted in the affective variables literature that major language skills can be anxiety-provoking by themselves. For instance, Saito, Horwitz and Garza (1999) demonstrated that reading grades of learners of English as an FL decrease parallel to their levels of reading anxiety and general FL anxiety. FL writing was also proved to be inhibited by writing anxiety by Cheng, Horwitz and Schallert (1999). Horwitz et al. (1986) also demonstrated anxiety in speaking situations in an FL learning environment.

Researchers who have investigated listening skills have also reached the concensus that FL listening creates anxiety (Young, 1992; Bacon, 1989). They agree that FL listening may provoke anxiety, for it may sometimes be incomprehensible for the learner. In Krashen's terms, listening anxiety may act as an affective filter, which makes comprehension harder (1988). When listening comprehension becomes harder, listening anxiety present in the learner becomes more prevalent. This creates a cycle which needs to be broken to allow for the proper comprehension of what is being listened to. FL listening anxiety, therefore, has arisen as a concept worth studying from a psycholinguistic perspective. There have been numerous studies focusing on the nature, sources, and solutions of FL listening anxiety. However, no study has tried to identify a link between FL listening anxiety and listening text type whatsoever. The purpose and the research concern of the current study can, thus, be said to illustrate any possible link between the two concepts. 


\subsection{Literature Review}

Horwitz et al. (1986) pointed to the fact that anxiety levels of language learners influence their performance and proficiency levels in an FL. They found strong anxiety in listening as well as in speaking and testing situations. Following this study, scholars began to investigate different aspects of the issue. They have focused on various variables that affect and are affected by Foreign Language Classroom Anxiety (FLCA). They have also concentrated on different major skills and subskills of language proficiency that are influenced badly by high levels of language anxiety. In this investigation process, one issue which was focused on by scholars was to what extent FL listening is capable of creating anxiety. Scarcella and Oxford (1992) were among the first to suggest that listening tasks are likely to become anxiety-provoking for listeners when they are difficult or unfamiliar to them. This problem is also related to the learners' learning goals and beliefs. A listener, for example, may assume that $\mathrm{s} / \mathrm{he}$ must understand each and every word in a listening text. When this theory fails, anxiety inevitably occurs. If the learner insists on not changing the theory, anxiety becomes a repetitive event. How learners perceive their own listening ability may be another source of foreign language listening anxiety or vice versa. MacIntyre (1995a) also emphasized the FL students' worry about misunderstanding linguistic structures or inferring meaning from situational context because they make embarrassing mistakes in such activities. Recently, the findings of other studies (Kimura, 2011; Golchi, 2012) showed that listening anxiety is negatively correlated to listening comprehension. In the current study, the authors tried to establish a relationship between levels of listening anxiety and listening proficiency to buttress the assertion that listening tasks can become anxiety-provoking.

Another research focus related to listening anxiety was the sources from which this type of anxiety originates. Wheeless and Scott (1976) explain the source of listening anxiety in L2 as it relates to three factors. The first one is a situation-specific worry of facing new information. The second factor is related to the fear of information processing or psychologically adjusting to messages. The third factor creating listening anxiety is related to the use of interpretive schemes or strategic repertoires to respond to incoming information. Therefore, the learners who lack the appropriate schemata to strategically process messages tend to feel anxious over a variety of situations. It was assumed by the authors of the current study that listening text type can challenge listeners by presenting different types of interpretive schemes that they need to process in order to comprehend messages. When they do not have the appropriate schemata, they may feel differing levels of anxiety while listening to different listening text types.

In another study, Vogely (1998) conducted a research to present the sources of and solutions for listening comprehension anxiety as reported by foreign language students. The students in her study associated listening anxiety with the characteristics of listening comprehension input and process-related factors more so than instructional factors and personal and interpersonal variables. Their solutions for lowering listening comprehension anxiety involved instructional factors and input characteristics. Vogely concludes that if listening comprehension activities target listening anxiety, this will strengthen both the teacher and the learner. If teachers direct their students' focus to understanding the message rather than being 'correct', their motivation will increase and their anxiety will decrease. "Learners that are motivated to listen and learn will have positive attitudes toward the target language and its speakers" (p. 75-76). Vogely associates listening anxiety with input characteristics. The research concern of the current study is listening text type, which is one of the most important characteristics of the auditory input that a listener is exposed to. Therefore, we can base our findings on Vogely's assertion that the characteristics of the listening input (i.e. listening text) influences the extent to which listeners feel anxiety.

Sharif and Ferdous (2012) analyzed the sources of Listening Comprehension (LC) anxiety based on self-reports of language teachers and learners. They concluded that the sources of listening anxiety may be related to factors concerning teachers and learners, materials and process, and other factors. This study also justifies the need to probe into listening text type as a material-and-process-related factor which can generate anxiety in listening situations.

More recently, Kim (2000) devised a research on foreign language listening anxiety, which forms the basis for the current study. The author looked for a relationship between FL listening and anxiety. Her thesis had two components, the first of which examined the existence of listening anxiety and general foreign language anxiety quantitatively. The second component which was qualitative analyzed the sources and effects of listening anxiety The assumption was that the students had an adequate range of emotional experiences with listening to English to participate in an anxiety study because they had been exposed to a series of listening texts in their English classes. 
The results of Kim's study (2000) suggested that FL learners indeed experience anxiety in response to listening comprehension tasks, which is afact accepted by other scholars studying in the listening comprehension field (Horwitz et al., 1986; Bacon, 1989; Young, 1992). A majority of the participants in the study acknowledged having experienced listening anxiety in FL classrooms and real-life communication situations. These results were also confirmed by the qualitative component of the dissertation. The current study tried to establish a link between listening anxiety and listening proficiency so as to support the notion that listening anxiety has a debilitative effect on listening proficiency. Kim's study also revealed that Foreign Language Listening Anxiety Scale (FLLAS) is a reliable and valid measure of foreign language listening anxiety. The analyses of internal consistency and test-retest reliability all proved that FLLAS is a reliable measure. The authors of the current study, therefore, decided to use FLLAS to measure the general listening anxiety levels of the participants. Kim also found a significant correlation between listening anxiety and foreign language anxiety. However, the squared correlation showed that half of the variance of the FLLAS was not explained by variation in the FLCAS. Kim concludes that "the two constructs seem to be not only associated, but also relatively independent" (2000: 148). The rest of the variance may be due to other factors or sampling error. This result corresponds with Elkafaifi's (2005) result that FL learning anxiety and listening anxiety are separate but related phenomena that both correlate negatively with achievement.

In another study, Mills, Pajares and Herron (2006: 276) indicated that listening anxiety was positively related to the listening proficiency of both male and female participants. This implies that listening anxiety may be related to listening proficiency with gender as a modifying factor. We tried to replicate this finding with Turkish students of English as an FL.

It is generally accepted in the listening comprehension literature that listening comprehension presents a great challenge to learners of English regardless of their purposes for learning. Bozorgian (2012) argues that this challenge may induce "feelings of frustration, poor listeners' performance, or inadequate attention paid in the classroom" (p. 1). According to him, listening input is implicit and complex due to external factors related to speaker, text, and/or content. Since listening text type is an external factor which can make listening input difficult to comprehend, the authors of the current study felt it necessary to assess the effect of text type on listening anxiety levels of learners of English. Thus, we believe that this issue is an important one to be tested with an empirical study.

\subsection{Importance of the Problem and Research Questions}

In the light of the above-mentioned studies, it is possible to argue that foreign language listening anxiety (FLLA) creates an impact on listening comprehension. Whether listening text type can affect listeners' FLLA levels remains as an issue that needs to be investigated in its potential for affecting learners' listening performance. The present study tried to find an answer to this question. Thus, it added a new dimension to the listening anxiety issue. The existence of listening anxiety has been proved by the studies mentioned above and it was established that foreign language learning anxiety and listening anxiety are separate but related phenomena (Elkhafaifi, 2005). The focus of the current study is, therefore, to find out whether listening anxiety is affected by the listening text type. The present study will also question whether or not listening proficiency is affected by the participants' listening anxiety levels. In sum, it can be said that this study is a descriptive analysis of the participants' listening anxiety levels and it also aims to probe into the relationship between foreign language listening anxiety and listening text type. Having discussed the objectives of the study, we can summarize the research questions of the study as follows:

1. Does listening text type affect the listening anxiety levels of Turkish learners of English?

2. Is there a statistically significant relationship between the listening anxiety levels and listening proficiency levels of Turkish learners of English?

\section{Method}

\subsection{Participants}

The sample for the study consisted of 130 prospective students of the Engineering Faculty presently studying in the preparatory English classes of Gaziantep University. The ages of the participants ranged from 17 to 27 with an average age of 19.6. The male-female ratio was 103:27. The proficiency levels of the students were determined at the beginning of the semester using a placement test prepared by the School of Foreign Languages. The test yielded an alpha reliability coefficient of .86 and a test-retest reliability of .79 . The face validity of the test was checked by 7 instructors in the School of Foreign Languages and found to be adequate for the specified curricular objectives. The placement test demonstrated that the majority of the participants (n:71, \%: 45.2) had a 
pre-intermediate level of proficiency in English, while 49 (\%: 31.2) were intermediate and 37 (\%: 23.6) were upper-intermediate level English learners. The participants were studying in 6 different language classes ( 2 for each proficiency level), so the sampling procedure was cluster sampling.

\title{
2.2 Research Instruments
}

\subsubsection{Foreign Language Listening Anxiety Scale (FLLAS)}

Since Wheeless' (1975) widely used Receiver Apprehension Test was specifically designed for first language acquisition, Kim (2000) felt the need to design a scale applicable to the FL learning context when measuring listening anxiety. After a thorough preparation and reviewing process, she developed a scale called Foreign Language Listening Anxiety Scale (FLLAS). The details of the development of this scale has been provided in the literature review section.

For the current study, the items in the FLLAS were translated into Turkish by the author. Then, the translated version was back-translated by three ELT graduate students and the problematic translations were modified. Colleagues from the Turkish Language Department were asked to evaluate the final version of the translation and the minor details which may lead to misunderstandings were corrected accordingly.

\subsubsection{Anxometer}

The current study tried to determine the anxiety levels of the participants while they were listening to an L2 text. The instrument used for this purpose is an anxometer adopted from MacIntyre and Gardner (1991). Participants are asked to grade their anxiety levels on a scale of 1-10 after listening to texts of different types. Figure 2 shows the anxometer used in the scale and the three band categories for high, moderate and low anxiety levels.

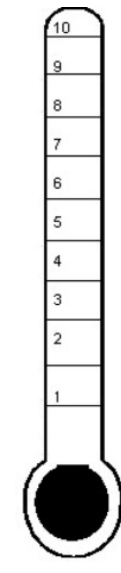

\author{
8-10 : High Anxiety Level \\ 5-7 : Moderate Anxiety Level \\ 1-4: Low Anxiety Level
}

Figure 1. Anxometer (MacIntyre and Gardner, 1991)

\subsubsection{Listening Texts for the Elicitation of Listening Anxiety}

For the elicitation of listening anxiety, nine listening passages were used. Three of these passages were dialogues from everyday life; three were lectures; and the remaining three were extracts from radio talk shows. These three listening types were chosen because the first one reflects the colloquial usage of English; the second one is an example of the academic use of English; and the last type relates to the usage of English in the media which can be regarded as a separate genre. The passages were kept a little above the students' current listening competence at all three levels with the assumption that the students would experience listening anxiety when they had to participate in activities which were necessarily more challenging. The difficulty of the passages was checked by the classroom teachers.

The listening texts were chosen from Randall's ESL Cyber Listening Lab (available at http://www.esl-lab.com/). The average word count for the texts were 320 and there were follow-up questions which would both give a purpose to the students for listening to the passages and help to make the anxiety more obvious to them.

\subsubsection{Yearlong Listening Test Scores as the Indicator of Listening Proficiency}

Since the current study aims to find out the relationship between listening anxiety and listening proficiency, it was necessary to measure participants' listening proficiency levels. As students in the intensive language program of the mentioned university, the participants were administered a total of 20 quizzes and 6 mid-terms throughout the whole academic year. Each one of these examinations included a separate listening section. The 
researchers used participants' average scores from these listening sections as an indicator of their listening proficiency.

\subsection{Data Collection and Analysis}

A pilot study was conducted in order to measure the time needed to fill out the questionnaires, to clarify the data collection procedures, and to measure the internal consistency of the questionnaire. The questionnaire was administered to fifty-eight students from the intermediate proficiency group who were not participating in the main study. The alpha $(\alpha)$ reliability score for the FLLAS was .90 , which showed that the questionnaire would reliably serve the purpose of the study.

The participants were administered the FLLAS at the beginning of the study to determine their existing listening anxiety levels. To analyze the anxiety levels with different text types, the researchers periodically (a total of three times) had participants listen to three different types of listening passages within their classrom medium at an interval of one and a half months between each administration. Just after listening to the passages, the participants were asked to mark their anxiety levels on the anxometer. The aim was to determine the level of listening anxietyprovoked by each type of listening text.

Having collected all the data required for the investigation, the researchers typed the data into SPSS 15.0, which is a package programme for statistical analyses in social sciences. The first step was to gather the Cronbach's Alpha value for the FLLAS. Then, the scores obtained through anxometer were run in a one-way ANOVA in order to see the effect of text type on participants' listening anxiety levels.

\section{Findings}

In this section, the results of the statistical analyses conducted in response to the research questions will be presented. The two research questions will be answered separately.

Is there a statistically significant relationship between the listening anxiety levels and listening proficiency levels of Turkish learners of English?

In order to answer the research question above, a Pearson product moment correlation was used. Pearson product moment correlation is the most commonly used type of correlation. According to Hatch and Farhady (1981: 203), there are some underlying assumptions that have to be met for Pearson correlation analysis. "The assumptions are: (1) the two variables are continuous, (2) scores on $\mathrm{X}$ and $\mathrm{Y}$ are independent of each other, and (3) the relationship between $\mathrm{X}$ and $\mathrm{Y}$ is linear". Since we can meet these assumptions for the present study, Pearson product moment correlation was the appropriate method to be used. The Pearson product moment correlation indicated that there is a significant negative correlation between subjects' FLLA scores and their listening proficiency scores at the $\mathrm{p}>.01$ level $(\mathrm{r}=-.301)$. This means that as listening anxiety increases, listening proficiency decreases and vice versa. This correlation value is a clear indicator of the relationship between listening anxiety and listening proficiency. Kim (2000) also found that foreign language listening anxiety correlated negatively with listening proficiency $(r=-.364, \mathrm{p}>.01)$. This finding is also in line with the listening comprehension studies suggesting that there is a negative correlation between listening anxiety and listening proficiency (Horwitz et al., 1986; Scarcella and Oxford, 1992; Kimura, 2011; Golchi, 2012).

Does the type of the listening text affect the listening anxiety levels of Turkish learners of English?

In order to answer this research question, a one-way ANOVA was conducted. In order to meet the assumptions of the one-way ANOVA, the researchers made certain that the sample size was of an adequate size; the groups were independent of each other; the skewness value of -.073 was indicative of a normal distribution; the Levene's test was found to be greater than .05 (sig.=.223) indicating that the population variances are equal; and final observance was to use a scale variable for the dependent variable. The results of the one-way ANOVA are presented in Table 1:

Table 1. Summary of the One-way ANOVA for Anxiety Level and Text Type

\begin{tabular}{llllll}
\hline & Sum of Squares & df & Mean Square & F & Sig. \\
\hline Between Groups & 533.692 & 2 & 266.846 & 67.304 & .000 \\
Within Groups & 1431.283 & 361 & 3.965 & & \\
Total & 1964.975 & 363 & & & \\
\hline
\end{tabular}


The ANOVA table shows that the anxiety levels measured by the anxometer were significantly difference for the three text types $($ sig. $=.000$ ). Next, a post hoc test was conducted in order to identify significant differences among the pairs of text types. Table 2 illustrates the findings of the Scheffe post hoc test:

Table 2. Summary of the Scheffe Post-Hoc Test for Anxiety Level and Text Type

\begin{tabular}{lllllll}
\hline & & $\begin{array}{l}\text { Mean } \\
\text { Difference }\end{array}$ & & & Lower & Upper \\
(I) Text Type & (J) Text Type & (I-J) & Std. Error & Sig. & Bound & Bound \\
\hline Dialogue & Lecture & $-1.53761^{*}$ & .25374 & .000 & -2.1613 & -.9139 \\
& Radio Talk Show & $-2.93932^{*}$ & .25374 & .000 & -3.5630 & -2.3156 \\
Lecture & Dialogue & $1.53761^{*}$ & .25374 & .000 & .9139 & 2.1613 \\
& Radio Talk Show & $-1.40171^{*}$ & .26033 & .000 & -2.0416 & -.7618 \\
Radio Talk Show & Dialogue & $2.93932^{*}$ & .25374 & .000 & 2.3156 & 3.5630 \\
& Lecture & $1.40171^{*}$ & .26033 & .000 & .7618 & 2.0416 \\
\hline
\end{tabular}

*. The mean difference is significant at the 0.05 level.

The multiple comparisons table shows that the mean differences are significant between the text types of dialogue and lecture $(-1.53761$, sig. $=.000)$, dialogue and radio talk show $(-2.93932$, sig. $=.000)$, and lecture and radio talk show $(-1.40171$, sig. $=.000)$. The indication is that FL learners are sensitive to the differences of listening text type.

In order to be able to comment on the probabilistic reasons for the differential amounts of FLLA experienced by EFL listeners, the researchers attempted an analysis on the average speech rates of the three different text types used in the current study. The results are presented in Table 3:

Table 3. Average Speech Rates for the Three Different Text Types

\begin{tabular}{lllll}
\hline Text Type & Words / minute & Syllables / minute & Syllables / word & Words / sentence \\
\hline Dialogues & 200 & 250 & 1.25 & 7.2 \\
Lectures & 187 & 246 & 1.37 & 20.2 \\
Radio Talk Shows & 219 & 277 & 1.27 & 13.3 \\
\hline
\end{tabular}

Based on the results of the analysis presented in Table 3, there is a strong likelihood that the difference among the text types basically lies in the fact that radio talk shows include more words per minute (wpm). In a dialogue, speakers utter $200 \mathrm{wpm}$. In a lecture, the number decreases to 187. In a radio talk show, which has the fastest rate of speech of all, speakers utter approximately $219 \mathrm{wpm}$. Thus, it could be the speed of delivery, which makes these texts difficult to comprehend, thereby leading to anxiety. In line with this finding, the syllable per minute (spm) ratio is also the highest in radio talk shows (277 spm).

Another striking finding is that the number of words per sentence (wps) was the highest in lectures (20.2 wps), meaning that the sentences used in the lectures were longer than those used in dialogues. Trying to follow and make sense of longer sentences might be another reason why lectures are more anxiety-provoking than dialogues. For radio talk shows, the wps ratio was 13.3, and for dialogues, it was 7.2. To sum up, speech rate could also be an important variable in determining listening anxiety. Buck (2001) suggests that "comprehension declines as the speaker talks faster, and the weight of the evidence suggests that the decline in comprehension is rather slow until a threshold level is reached, at which time an increased speech rate leads to a much more rapid decline in comprehension" (p. 40). Since there is wide-ranging agreement on the fact that comprehension and anxiety are negatively related concepts, this may be the reason why different text types create differing amounts of listening anxiety in EFL listeners.

\section{Discussion and Conclusion}

The primary concern of the present study was to explore the effects of different listening text types on EFL learners' listening anxiety levels. More specifically, the relationship between listening text type and FLLA was investigated. The study had a comparative focus, that is, the differential effects of three different listening text types (i.e. dialogue, lecture, and radio talk show) were compared with each other in terms of the anxiety induced on listeners. 
The current study found that FLLA correlates negatively with listening proficiency. For the relationship between listening proficiency and listening anxiety, this study revealed a moderately significant negative correlation. This finding indicates that lower levels of listening proficiency are correlated with higher listening anxiety. This finding is also consistent with Aneiro's (1989) study, in which a similar negative correlation was obtained. Kim (2000) also found a moderate association between the two constructs. In conformity with the results of the current study, a significant linear relationship was found to exist between listening comprehension and receiver apprehension in Fitch-Hauser, Barker and Hughes's 1990 study.

Previously, Kim (2000) had indicated that EFL learners are sensitive to the text and task type, that is, their levels of listening anxiety change according to the listening text type. However, this claim was based on some retrospective interviews. The current study made a quantitative evaluation of that claim. One-way ANOVA procedures established that text type has a differential effect on EFL learners' levels of listening anxiety. While lecture and radio talk show created the higher levels of anxiety in an increasing order, informal dialogue ( $\mathrm{M}=$ 3.84) caused the least anxiety in the participants of the study. These represent the types of listening texts used in the participants' classrooms. The listening activities employed in the classrooms mostly include scripted dialogues, which induces the least anxiety in the listeners. Lectures pose more challenge to the students because they are not familiar with the linguistic (not to mention the discoursal) features of this text type. Radio talk show is the most anxiety-provoking of all, since its pace, intonation, stress,pronunciation and fragmented sentence features are truly close to being authentic. Therefore, we can draw the conclusion that the authenticity (i.e. real-world-likeness) of a listening text leads to more listening anxiety.

\section{References}

Aneiro, S. (1989). The Influence of Receiver Apprehension in Foreign Language Learners on Listening Comprehension among Puerto Rican College Students. Unpublished Doctoral Dissertation, New York University, New York.

Bacon, S. M. (1989). Listening for real in the foreign-language classroom. Foreign Language Annals, 22(6), 543-551. http://dx.doi.org/10.1111/j.1944-9720.1989.tb02781.x

Bozorgian, H. (2012). Metacognitive instruction does improve listening comprehension. ISRN Education, 1-6. http://dx.doi.org/10.5402/2012/734085

Buck, G. (2001). Assessing Listening (pp. 7-20). Cambridge University Press, Cambridge. http://dx.doi.org/10.1017/CBO9780511732959

Cheng, Y., Horwitz, E. K., \& Schallert, D. L. (1999). Language anxiety: differentiating writing and speaking components, Language Learning, 49(3), 417-446. http://dx.doi.org/10.1111/0023-8333.00095

Elkhafaifi, H. (2005). Listening comprehension and anxiety in the Arabic language classroom. Modern Language Journal, 89(2), 206-220. http://dx.doi.org/10.1111/j.1540-4781.2005.00275.x

Ellis, R. (1995). The Study of Second Language Acquisition. Oxford University Press, Oxford.

Fitch-Hauser, M., Barker, D. A., \& Hughes, A. (1990). Receiver apprehension and listening comprehension: A linear or curvilinear relationship. The Southern Communication Journal, 56, 62-71. http://dx.doi.org/10.1080/10417949009372816

Golchi, M. M. (2012). Listening anxiety and its relationship with listening strategy use and listening comprehension among Iranian IELTS learners. International Journal of English Linguistics, 2(4), 115-128. http://dx.doi.org/10.5539/ijel.v2n4p115

Hatch, E., \& Farhady, H. (1981). Research Design and Statistics for Applied Linguistics. Newbury House Publishers, Rowley, MA.

Horwitz, E. K., Horwitz, M. B., \& Cope, J. (1986). Foreign language classroom anxiety. The Modern Language Journal, 70, 125-132. http://dx.doi.org/10.1111/j.1540-4781.1986.tb05256.x

Kim, J. (2000). Foreign Language Listening Anxiety: A Study of Korean Students Learning English. Unpublished Doctoral Dissertation, The University of Texas at Austin, Texas, pp. 19-75.

Kimura, H. (2011). A Self-Presentational Perspective on Foreign Language Listening Anxiety. Unpublished Doctoral Dissertation, Temple University, Philadelphia, USA.

Krashen, S. (1988). Second Language Acquisition and Second Language Learning. New York, Prentice Hall International Inc.

MacIntyre, P. D. (1995a). How does anxiety affect second language learning? A reply to Sparks and Ganschow. 
The Modern Language Journal, 79, 90-99. http://dx.doi.org/10.1111/j.1540-4781.1995.tb05418.x

MacIntyre, P. D., \& Gardner, R. C. (1989). Anxiety and second language learning: Toward a theoretical clarification. Language Learning, 39, 251-257. http://dx.doi.org/10.1111/j.1467-1770.1989.tb00423.x

MacIntyre, P. D., \& Gardner, R. C. (1991). Investigating language class anxiety using the focused essay tecnique. The Modern Language Journal, 75, 296-304.

Mills, N., Pajares, F., \& Herron, C. (2006). A reevaluation of the role of anxiety: Self-efficacy, anxiety, and their relation to reading and listening proficiency. Foreign Language Annals, 39(2), 276-295. http://dx.doi.org/10.1111/j.1944-9720.2006.tb02266.x

Saito, Y., Horwitz, E., \& Garza, J. (1999). Foreign Language Reading Anxiety. The Modern Language Journal, 83, 202-218. http://dx.doi.org/10.1111/0026-7902.00016

Scarcella, R., \& Oxford, R. (1992). The Tapestry of Language Learning: The Individual in the Communicative Classroom. Heinle \& Heinle, Boston, MA.

Sharif, M. Y., \& Ferdous, F. (2012). Sources and Suggestions to Lower Listening Comprehension Anxiety in the EFL Classroom: A Case Study. English Language Teaching, 5(10), 92-105. http://dx.doi.org/10.5539/elt.v5n10p92

Vogely, A. J. (1998). Listening comprehension anxiety: Students' reported sources and solutions. Foreign Language Annals, 31(1), 67-80. http://dx.doi.org/10.1111/j.1944-9720.1998.tb01333.x

Wheeless, L. R. (1975). An investigation of receiver apprehension and social context dimensions of communication apprehension. The Speech Teacher, 24, 261-268. http://dx.doi.org/10.1080/03634527509378169

Young, D. J. (1992). Language anxiety from the foreign language specialist's perspective: Interviews with Krashen, Omaggio Hadley, Terrell, Rardin. Foreign Language Annals, 25, 157-172. http://dx.doi.org/10.1111/j.1944-9720.1992.tb00524.x 